\title{
A Brain L-Type Calcium Channel $\alpha 1$ Subunit Gene (CCHL1A2) Maps to Mouse Chromosome 14 and Human Chromosome 3
}

\author{
Hemin Chin, ${ }^{*, 1}$ Christine A. Kozak, † Hyung-Lae Kim, ${ }^{*}$ Beverly Mock، $\ddagger$ and O. Wesley McBride§ \\ *Laboratory of Molecular Biology, NINDS, †Laboratory of Molecular Microbiology, NIAID, ¥Laboratory of Genetics, \\ and §Laboratory of Biochemistry, NCl, National Institutes of Health, Bethesda, Maryland 20892
}

Received March 28, 1991; revised July 18, 1991

\begin{abstract}
A rat brain cDNA probe was used to localize a gene encoding the $\alpha 1$ subunit of neuronal dihydropyridine-sensitive L-type calcium channels in the mouse and human genomes. Hybridization of the probe to Southern blots made with DNAs from a Chinese hamster $X$ mouse somatic cell hybrid panel indicated that this gene maps to mouse chromosome 14 (Chr 14). Southern blot analysis of an intersubspecies cross demonstrated that the calcium channel $\alpha 1$ subunit gene, termed Cchlla2, can be positioned $7.5 \mathrm{cM}$ proximal to $N p-1$. Similarly, segregation among human $\mathrm{X}$ rodent somatic cell hybrids indicated that CCHL1A2 maps to human chromosome 3 . These assignments are consistent with a region of linkage homology between human chromosome 3p and a proximal region of mouse Chr 14. () 1991 Academic Press, Inc.
\end{abstract}

\section{INTRODUCTION}

Calcium entry through voltage-sensitive calcium channels (VSCC) mediates several essential physiologic functions, including muscle contraction and neurotransmitter and hormone secretion. Multiple types of VSCCs, designated T, N, L, and P, have been identified in vertebrate cells, based on their electrophysiologic and pharmacologic properties (Nowycky et al., 1985; Llinas et al., 1989). The slowly inactivating Ltype VSCC is activated by strong depolarization and is sensitive to organic $\mathrm{Ca}^{2+}$ channel blockers such as 1,4-dihydropyridines (DHPs), phenylalkylamines, and benzothiazepines. L-type calcium channels were first purified from rabbit skeletal muscle $T$-tubule membranes and have been shown to have multimeric structure consisting of five distinct polypeptide subunits ( $\alpha 1, \alpha 2, \beta, \gamma, \delta$; reviewed in Campbell et al., 1988; Catterall et al., 1988). Detailed biochemical and molec-

\footnotetext{
${ }^{1}$ To whom correspondence should be addressed at Laboratory of Molecular Biology, Building 36, Room 3D-02, NINDS, National Institutes of Health, Bethesda, MD 20892.
}

ular cloning studies further indicate that the functional protein of the DHP-sensitive L-type calcium channel is the large, transmembrane $\alpha 1$ subunit. cDNA clones encoding $\alpha 1$ subunits isolated from skeletal and cardiac muscles express functional calcium channel activity when transfected into fibroblasts or microinjected into myotubes (Perez-Reyes et al., 1989; Tanabe et al., 1988). Recently, we isolated a third type of $\alpha 1$ subunit cDNA (DHPR-B) from rat brain cDNA libraries based upon shared sequence homology with the skeletal muscle $\alpha 1$ subunit cDNA (Chin et al., 1991). In brain, the DHPR-B cDNA identified an $\sim 10-\mathrm{kb}$ mRNA transcript that is preferentially localized in those areas involved in neuroendocrine functions. The skeletal muscle, cardiac muscle, and brain types of the $\alpha 1$ subunit cDNA share a high degree of structural homology and nucleotide sequence conservation and are encoded by separate genes. Here we report the chromosomal locations in mouse and humans of the gene encoding the $\alpha 1$ subunit of the neuronal calcium channel.

\section{MATERIALS AND METHODS}

\section{Somatic Cell Hybrids}

Production and characterization of Chinese hamster $\times$ mouse somatic cell hybrids have been described previously (Hoggan et al., 1988). Panels of human $\times$ mouse and human $\times$ Chinese hamster cell lines containing subsets of human chromosomes in a rodent chromosome background were previously described (McBride et al., 1982a,b, 1984). Both sets of hybrids were characterized by karyotypic analyses of banded mitotic chromosomes and electrophoretic assays of human or mouse biochemical markers (Hoggan et al., 1988; McBride et al., 1982a,b, 1984).

\section{Mice}

NFS/N strain mice were obtained from the Division of Natural Resources, NIH (Bethesda, MD). 
C58/J mice were obtained from The Jackson Laboratory (Bar Harbor, ME). Mus musculus musculus mice came from a laboratory colony derived from mice originally trapped in Skive, Denmark, and maintained by Dr. M. Potter (NCI, NIH, Contract N01-CB2-5584) at Hazleton Laboratories (Rockville, MD). NFS/N or $\mathrm{C} 58 / \mathrm{J}$ females were mated with $M$. m. musculus males, and the F1 females were backcrossed with $M$. $m$. musculus males to produce the experimental animals. Kidney extracts from the backcross progeny were typed for $N p-1$ (nucleoside phosphorylase-1) and $E s-10$ (esterase-10) by histochemical staining on starch gels (Harris and Hopkinson, 1976). Rbp-3 (interphotoreceptor retinoid-binding protein) was typed by Southern blot analysis for an XbaI polymorphism (Danciger et al., 1990).

\section{Blot-Transfer Hybridization}

DNAs were extracted from Chinese hamster $\times$ mouse cell hybrids and mouse livers, cleaved with appropriate restriction enzymes, run on $0.4 \%$ (backcross progeny) or $0.7 \%$ (somatic cell hybrids) agarose gels, and transferred to nylon membranes (Hybond $\mathrm{N}^{+}$or Zetabind). The presence of the brain calcium channel $\alpha 1$ subunit gene in the hybrid cell lines was assayed by Southern blots (Southern, 1975) using a ${ }^{32} \mathrm{P}$-labeled insert representing a 740-bp EcoRIBstXI 5' fragment of the DHPR-B cDNA (Chin et al., 1991). The probe was labeled by a random hexomer priming method (Sambrook et al., 1989). Hybridizations and washings were performed under moderate stringency to allow detection of sequences with 20 $25 \%$ divergence.

\section{RESULTS}

\section{Cchlla Maps to Mouse Chr 14}

To map the gene encoding an $\alpha 1$ subunit of neuronal L-type $\mathrm{Ca}^{2+}$ channels, we analyzed $E c o$ RI restriction fragments of genomic DNA prepared from a number of Chinese hamster $\times$ mouse somatic cell hybrids. $E c o R I$ was chosen for these digests since it generates distinctive restriction fragments of $6.0 \mathrm{~kb}$ in mouse DNA and 2.2 and $3.9 \mathrm{~kb}$ in Chinese hamster cell DNA when hybridized with the rat brain calcium channel $\alpha 1$ subunit cDNA probe.

The presence or absence of EcoRI restriction frag ments hybridizing with the DHPR-B cDNA probe was scored in a panel of 21 Chinese hamster $\times$ mouse somatic cell hybrids, as indicated in Table 1 . A typical Southern blot from which these data were derived is shown in Fig. 1. Six of the somatic cell hybrids contained the 6.0-kb EcoRI mouse fragment. The results, summarized in Table 1, indicate that the gene encoding this protein, designated Cchl1a2, can be assigned

\section{TABLE 1}

Segregation of Cchl1a2 $\mathrm{Ca}^{2+}$ Channel $\alpha 1$ Subunit Gene and Mouse Chromosomes in EcoRI-Digested Hamster $\times$ Mouse Somatic Cell Hybrids

\begin{tabular}{|c|c|c|c|c|c|}
\hline \multirow[b]{2}{*}{ Chromosome } & \multicolumn{2}{|c|}{$\begin{array}{c}\text { Concordant } \\
\text { No. of } \\
\text { hybrids } \\
\end{array}$} & \multicolumn{2}{|c|}{$\begin{array}{c}\text { Discordant } \\
\text { No. of } \\
\text { hybrids } \\
\end{array}$} & \multirow{2}{*}{$\begin{array}{l}\text { Percentage } \\
\text { discordancy }\end{array}$} \\
\hline & $+1+$ & $-1-$ & $+1-$ & $-/+$ & \\
\hline 1 & 2 & 4 & 4 & 7 & 64.7 \\
\hline 2 & 5 & 5 & 1 & 6 & 41.2 \\
\hline 3 & 2 & 4 & 1 & 2 & 33.3 \\
\hline 4 & 1 & 7 & 4 & 4 & 50.0 \\
\hline 5 & 1 & 8 & 5 & 3 & 47.1 \\
\hline 6 & 3 & 7 & 3 & 4 & 41.2 \\
\hline 7 & 5 & 3 & 0 & 7 & 46.7 \\
\hline 8 & 3 & 6 & 3 & 3 & 40.0 \\
\hline 9 & 4 & 8 & 2 & 3 & 29.4 \\
\hline 10 & 1 & 10 & 5 & 1 & 35.3 \\
\hline 11 & 0 & 11 & 5 & 0 & 31.2 \\
\hline 12 & 0 & 2 & 1 & 4 & 71.4 \\
\hline 13 & 3 & 8 & 2 & 3 & 31.2 \\
\hline 14 & 5 & 10 & 1 & 0 & 6.2 \\
\hline 15 & 1 & 1 & 0 & 6 & 75.0 \\
\hline 16 & 3 & 9 & 2 & 2 & 25.0 \\
\hline 17 & 3 & 4 & 1 & 5 & 46.2 \\
\hline 18 & 2 & 4 & 4 & 4 & 57.1 \\
\hline 19 & 3 & 6 & 2 & 5 & 43.8 \\
\hline $\mathrm{X}$ & 2 & 4 & 4 & 7 & 64.7 \\
\hline
\end{tabular}

Note. Discordancy represents the presence of the gene in the absence of a chromosome $(+/-)$ or the absence of the gene despite the presence of the chromosome $(-/+)$, and the sum of these numbers divided by the total hybrids examined $(\times 100)$ represents the percentage discordancy. Six hybrids were karyotyped; 11 were typed for DNA or isozyme markers on specific mouse chromosomes.

to mouse Chromosome (Chr) 14. The single discordant clone, HM78, was not karyotyped, but was typed as lacking mouse Chr 14 because of the absence of mouse $E s-10$ activity and $R b p-3$ sequences. The presence of the calcium channel sequences suggests that this hybrid may retain a fragment of $\mathrm{Chr} 14$.

\section{Cchlla2 Is in the Proximal Region of Mouse Chr 14}

To define a more precise location for Cchl1a2 on mouse Chr 14, genomic DNAs from an intersubspecies backcross were examined by Southern hybridization analyses (Fig. 2). Parental M. m. musculus DNA contained a single DHPR-B cDNA-cross-reactive $B g l I I$ fragment of $8.2 \mathrm{~kb}$, and NFS/N and C58/J contained a fragment of $4.0 \mathrm{~kb}$. Fifty of the 106 progeny of the intersubspecies backcross [(NFS/N or C58/J $\times M$. m. musculus) $\times M$. m. musculus] contained the 4.0-kb fragment consistent with a single-gene segregation ratio. The BglII restriction fragment polymorphism was used to examine the cosegregation of 


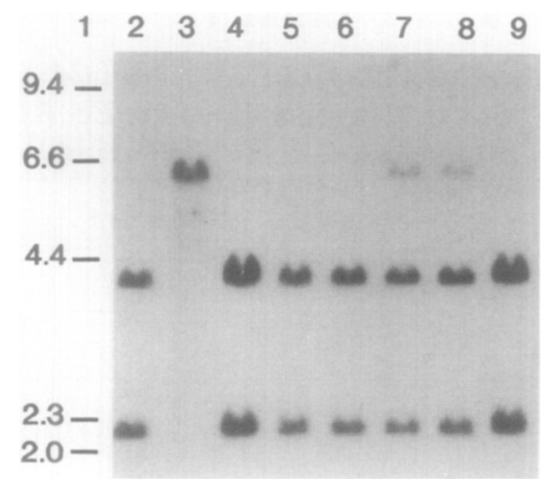

FIG. 1. Autoradiogram of a Southern blot of EcoRI-digested mouse $\times$ Chinese hamster somatic cell hybrid DNAs $(10 \mu \mathrm{g}$ per lane) hybridized with the rat brain DHPR-B cDNA probe. A different hybrid cell DNA is present in lanes 4 to 9. Parental E36 Chinese hamster cell line DNA (lane 2) and BALB/c mouse DNA (lane 3), along with HindIII cut $\lambda$ DNA molecular weight standard (lane 1), are also shown. The hybrid cell lines in lane 7 (HM84) and lane 8 (HM101) contain a 6.0 -kb mouse restriction fragment hybridizing with the DHPR-B cDNA probe.

Cchl1a2 alleles with those for two other Chr 14 markers (Es-10 and $N p-1)$. Eight recombinants were identified between Cchlla2 and Np-1; and 28 recombinants between Cchlla2 and Es-10 among 106 progeny (Table 2). Since $N p-1$ and $E s-10$ have established positions in the proximal half of Chr 14 (Hillyard et al., 1991; Lyon and Kirby, 1991), these data confirm the assignment of Cchlla2 to $\mathrm{Chr} 14$ and imply the following gene order: centromere-Cchlla2- $(7.5 \pm 2.5 \mathrm{cM})-$ $N p-1-(18.9 \pm 3.8 \mathrm{cM})-E s-10$.

\section{CCHL1A2 Maps to Human Chromosome 3}

The human CCHL1A2 gene was mapped by analysis of somatic cell hybrids. Panels of human $\times$ Chi-

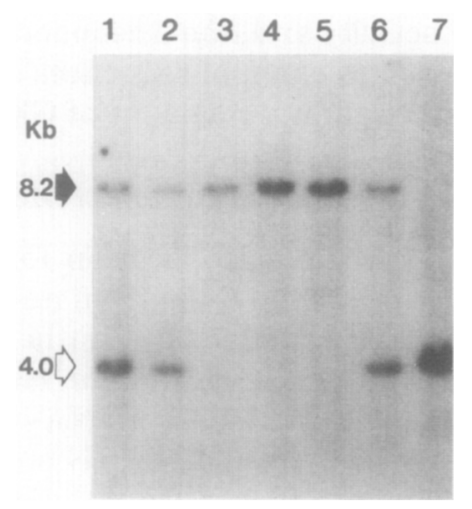

FIG. 2. Southern blot analysis of BglII-digested DNAs extracted from the progeny of an intersubspecies backcross. Lanes 1-6, individual backcross mice; lane 7, NFS/N parental DNA. Solid arrow indicates the $8.2-\mathrm{kb} M$. m. musculus DHPR-B cDNA reactive fragment; open arrow indicates the $4.0-\mathrm{kb}$ NFS/N fragment.
TABLE 2

Segregation of Cchl Ia2 Hybridizing Restriction Fragment with Alleles of $N p-1$ and $E s-10$ in 106 Progeny of an Intersubspecies Backcross

\begin{tabular}{|c|c|c|c|c|}
\hline \multirow[b]{2}{*}{ Mice } & \multicolumn{3}{|c|}{$\begin{array}{l}\text { Inheritance of the inbred } \\
\text { mouse allele }\end{array}$} & \multirow{2}{*}{$\begin{array}{l}\text { Number of } \\
\text { mice }\end{array}$} \\
\hline & CChl1a2 & $N p-1$ & Es-10 & \\
\hline \multirow[t]{2}{*}{ Parentals } & + & + & + & 33 \\
\hline & - & - & - & 45 \\
\hline \multirow[t]{5}{*}{ Single recombinants } & + & + & - & 12 \\
\hline & - & - & + & 8 \\
\hline & + & - & - & 5 \\
\hline & - & + & + & 3 \\
\hline & \multicolumn{4}{|c|}{ Recombinations $^{a}$} \\
\hline Locus pair & $r / n$ & \multicolumn{3}{|c|}{$\%$ recombination $( \pm \mathrm{SE})$} \\
\hline Cchlla2, Np-1 & $8 / 106$ & \multicolumn{3}{|c|}{$7.5 \pm 2.5$} \\
\hline$N p-1, E s-10$ & $20 / 106$ & \multicolumn{3}{|c|}{$18.9 \pm 3.8$} \\
\hline
\end{tabular}

${ }^{a}$ Percentage recombination between restriction fragments and standard error were calculated according to Ref. (7) from the number of recombinants $(r)$ in a sample size of $n$.

nese hamster (not shown) and human $\times$ mouse hybrids (Fig. 3) were analyzed. The human gene was detected as a $6.1-\mathrm{kb}$ EcoRI fragment, which was clearly resolved from the hamster $2.2-$ and $3.9-\mathrm{kb}$ hybridizing fragments. The human gene could not be distinguished from a cross-hybridizing mouse sequence in EcoRI digests. The human sequence was

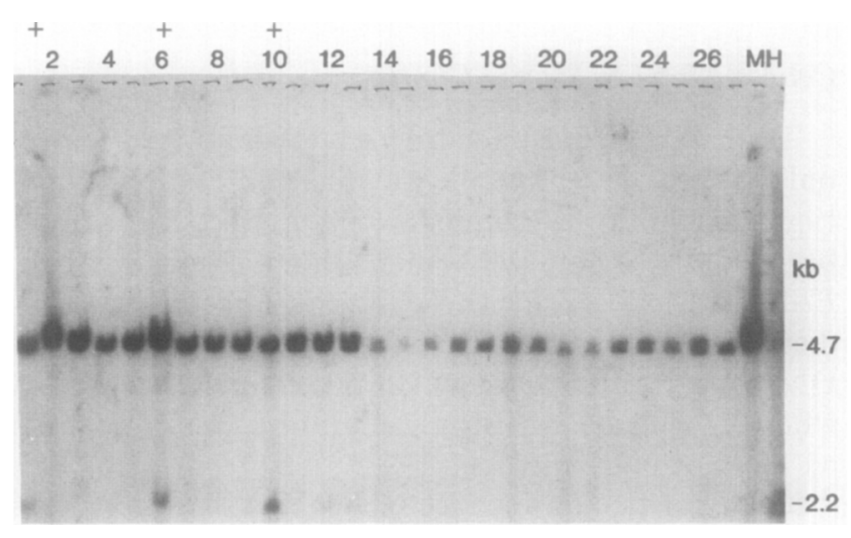

FIG. 3. Southern hybridization patterns of representative human $\times$ mouse somatic cell hybrids with the $5^{\prime}$ DHPR-B cDNA probe. Aliquots ( $10 \mu \mathrm{g}$ ) of DNA were digested with $B g I I I$, size fractionated by electrophoresis on agarose gels, and transferred to nylon membranes prior to Southern hybridization and autoradiography. A different hybrid cell DNA is present in each lane, and parental mouse (M) and human placental (H) DNAs are also shown. The sizes of hybridizing bands are presented. The presence of the hybridizing human $(2.2 \mathrm{~kb})$ sequence is indicated $(+)$ above the lanes. 
TABLE 3

\section{Segregation of CCHL1A2 $\mathrm{Ca}^{2+}$ Channel $\alpha 1$ Subunit Gene with Human Chromosome 3}

\begin{tabular}{|c|c|c|c|c|c|}
\hline \multirow[b]{2}{*}{ Chromosome } & \multicolumn{2}{|c|}{$\begin{array}{c}\text { Concordant } \\
\text { No. of } \\
\text { hybrids } \\
\end{array}$} & \multicolumn{2}{|c|}{$\begin{array}{c}\text { Discordant } \\
\text { No. of } \\
\text { Hybrids } \\
\end{array}$} & \multirow{2}{*}{$\begin{array}{l}\text { Percentage } \\
\text { discordancy }\end{array}$} \\
\hline & $+/+$ & $-1-$ & $+/-$ & $-/+$ & \\
\hline 1 & 21 & 47 & 13 & 11 & 26 \\
\hline 2 & 18 & 49 & 16 & 9 & 27 \\
\hline 3 & 34 & 58 & 0 & 0 & 0 \\
\hline 4 & 33 & 34 & 1 & 24 & 27 \\
\hline 5 & 21 & 54 & 13 & 4 & 18 \\
\hline 6 & 24 & 35 & 10 & 23 & 36 \\
\hline 7 & 12 & 32 & 22 & 26 & 52 \\
\hline 8 & 22 & 46 & 12 & 14 & 28 \\
\hline 9 & 21 & 47 & 13 & 11 & 26 \\
\hline 10 & 14 & 52 & 20 & 6 & 28 \\
\hline 11 & 20 & 48 & 14 & 10 & 26 \\
\hline 12 & 23 & 41 & 11 & 17 & 30 \\
\hline 13 & 16 & 38 & 18 & 20 & 41 \\
\hline 14 & 16 & 33 & 18 & 25 & 47 \\
\hline 15 & 18 & 33 & 16 & 25 & 45 \\
\hline 16 & 13 & 35 & 21 & 23 & 48 \\
\hline 17 & 22 & 22 & 12 & 36 & 52 \\
\hline 18 & 26 & 35 & 8 & 23 & 34 \\
\hline 19 & 21 & 51 & 13 & 7 & 22 \\
\hline 20 & 24 & 43 & 10 & 15 & 27 \\
\hline 21 & 32 & 31 & 2 & 27 & 33 \\
\hline 22 & 18 & 48 & 16 & 10 & 28 \\
\hline $\mathrm{X}$ & 23 & 33 & 11 & 25 & 39 \\
\hline
\end{tabular}

Note. The calcium channel $\alpha 1$ subunit gene was detected as a 6-kb band in EcoRI digests, 6.1- and 9.6-kb bands in HindIII digests, and 2.1 - and 3.5-kb bands in XbaI digests after hybridization of human $\times$ rodent hybrid cell DNA Southern blots with the DHPR-B cDNA probe. Detection of the human gene is correlated with the presence or absence of each human chromosome in the group of somatic cell hybrids. Discordancy represents the presence of the gene in the absence of a chromosome $(+/-)$ or the absence of the gene despite the presence of the chromosome $(-/+)$, and the sum of these numbers divided by the total hybrids examined $(\times 100)$ represents the percentage discordancy. Human $\times$ hamster hybrids consisted of 27 primary clones and 13 subclones ( 15 positives out of 40 total) and the human $\times$ mouse hybrids represented 16 primary clones and 36 subclones (19 positives out of 52 total).

resolved from the mouse homologue in both $X b a I$ and $B g l I I$ digests; these blots were used to map the gene in human $\times$ mouse hybrids. The results, summarized in Table 3, demonstrate that the presence or absence of the CCHL1A2 gene was correlated with the presence or absence of human chromosome 3. The CCHL1A2 gene segregated discordantly with all other human chromosomes.

Examination of two hybrids that contained spontaneous breaks involving chromosome 3 permitted regional localization of the CCHL1A2 gene to either $3 p 26$ or 3p21-q23. These cell lines were examined with the probes for genes previously localized in spe- cific regions of this chromosome. One hybrid contained a large deletion in the short arm with loss of distal 3p marker RAF1 (3p25), THRB (3p24.1-p22), and ACY1 (3p21), but retention of DNF1552 (3p21.221.3) as well as two other more proximal 3p markers and all loci on 3q. This hybrid also retained D3S18 (3p26) (Hosoe et al., 1990) and CCHL1A. The break in the other hybrid was in $3 q$, and there was loss of all $3 p$ markers and GPX1 (3q11-q12) but retention of DBL (3q13-q23), AHSG (3q27-q29), and another anonymous $3 q$ marker. The CCHL1A2 gene was absent in this second hybrid containing 3q23-qter. It is interesting that the mouse homologue of RARB has been localized on Chr 14 (Ceci et al., 1990) and human homologue to 3p24 (Mattei et al., 1988). This region is deleted in one of the hybrids containing CCHL1A2, and it is thus likely that CCHL1A2 is located in the 3 p26 or 3 p21 regions retained in this hybrid.

\section{DISCUSSION}

In the present study, we have localized the gene for the $\alpha 1$ subunit of neuronal L-type $\mathrm{Ca}^{2+}$ channels in the mouse and human gene maps using rat brain DHPR-B cDNA as a probe. The L-type $\mathrm{Ca}^{2+}$ channel belongs to the supergene family of voltage-sensitive ion channels, which also includes voltage-sensitive $\mathrm{Na}^{+}$and $\mathrm{K}^{+}$channels. This gene family has probably evolved from a common ancestral gene (Hille, 1984), since there is a striking homology among these channel proteins in both their primary and secondary structures. Genetic mapping of only one of these genes has been reported; the gene for sodium channel type II $\alpha$ subunit has been mapped to human chromosome 2 (Litt et al., 1989).

Our results represent the first chromosomal localization for the $\mathrm{Ca}^{2+}$ channel genes. L-type $\mathrm{Ca}^{2+}$ channels are present in a variety of excitable and nonexcitable vertebrate cells and are important in excitation-contraction and excitation-secretion coupling mechanisms. While their biochemical properties have been well characterized, molecular bases for the diverse functions of $\mathrm{L}$-type $\mathrm{Ca}^{2+}$ channels are still poorly understood. Our molecular cloning of the rat brain cDNA (DHPR-B), which encodes an $\alpha 1$ subunit of L-type $\mathrm{Ca}^{2+}$ channels (Chin et al., 1991), was used to show that both the $\mathrm{L}$-type $\mathrm{Ca}^{2+}$ channel $\alpha 1$ subunit mRNA and protein are highly expressed in brain regions containing the pituitary and pineal glands and the suprachiasmatic nucleus of the hypothalamus, i.e., areas mainly involved in neuroendocrine functions. This localization suggests that the L-type $\mathrm{Ca}^{2+}$ channel encoded by the CCHL1A2 gene may play a role in excitation-secretion coupling in endocrine cells.

This gene maps to the proximal region of $\mathrm{Chr} 14$ in 
mice and to chromosome 3 in humans. Somatic cell hybrids were used to assign the murine Cchl1a2 sequence to $\mathrm{Chr}$ 14. Southern analysis of intersubspecies backcross progeny positioned Cchl1a2 proximal to $N p-1$, which would place it in the centromeric region of this chromosome based on the composite genetic maps of the mouse (Hillyard et al., 1991; Lyon and Kirby, 1991). Analysis of human $X$ rodent somatic cell hybrids indicated that the human CCHL1A2 gene is located in the region of chromosome 3p21-3q23 or 3p26. A recent study (Ceci et al., 1990) has mapped another locus, Rarb, in this same region of Chr 14 and the human homologue to chromosome 3 . The mapping of the brain calcium channel $\alpha 1$ subunit locus reported here is consistent with the presence of a region of conserved linkage between murine $\mathrm{Chr} 14$ and human chromosome 3 . Thus, the comparative mapping of the CCHL1A2 gene further extends our knowledge of syntenic homologies between mouse and human chromosomes (Nadeau, 1989).

Given their importance in modulating ion permeability and mediating cellular responses, it is not surprising to find that neuronal $\mathrm{Ca}^{2+}$ channels are involved in human disease. Lambert-Eaton myasthenic syndrome (LEMS) is an autoimmune disorder of neuromuscular transmission (Elmqvist and Lambert, 1968). Serum autoantibodies from LEMS patients inhibit rat anterior pituitary hormone release and ${ }^{45} \mathrm{Ca}^{2+}$ uptake (Login et al., 1987) and block voltagedependent calcium currents in chromaffin cells (Kim and Neher, 1988). These findings are consistent with presynaptic $\mathrm{Ca}^{2+}$ channels being a target for the antibodies. LEMS is often associated with small cell carcinoma (SCC) of the lung, and LEMS autoantibodies bind to $\mathrm{Ca}^{2+}$ channels present in SCC cells (Lennon and Lambert, 1989). Our present finding that the CCHL1A2 gene could be located on human 3p26 or 3 p21 is intriguing because SCC tumor cells have a deletion of the 3p14-p23 region (Whang-Peng et al., 1982). Furthermore, deletion in $3 \mathrm{p} 21$ is also associated with other major types of lung cancer (Kok $e t$ $a l ., 1987)$, implying that this region contributes to tumorigenesis in small cell lung cancer. Further localization studies of the human CCHL1A2 gene are currently underway.

\section{ACKNOWLEDGMENTS}

The technical assistance of Marianne Krall and M. Charlene Adamson is greatly appreciated. We also thank Devera G. Schoenberg for editorial assistance.

\section{REFERENCES}

1. Campbell, K. P., Leung, A. T., and Sharp, A. H. (1988) The biochemistry and molecular biology of the dihydropyri- dine-sensitive calcium channel. Trends Neurosci. 11: 425430.

2. Catterall, W. A., Seagar, M. J., and Takahashi, M. (1988). Molecular properties of dihydropyridine-sensitive calcium channels in skeletal muscle. J. Biol. Chem. 263: 35353538.

3. CeCI, J. D., Kinglsey, D. M., Silan, C. M., Copeland, N. G., AND JENKINS, N. A. (1990). An interspecific backcross linkage map of the proximal half of mouse Chromosome 14. Genomics 6: 673-678.

4. ChIN, H., KIM, H. L., SMITH, M. A., AND KIM, H. (1991). Neuronal L-type calcium channels: Molecular cloning of an $\alpha 1$ subunit cDNA and localization in rat brain. Submitted for publication.

5. Danciger, M., Kozak, C. A., Nickerson, J., Redmond, T. M., AND FARBER, D. B. (1990). Location of the gene for interphotoreceptor retinoid-binding protein to mouse Chromosome 14 near $N p-1$. Genomics 8: 727-731.

6. ElmQvist, D., AND LAMBERT, E. H. (1968). Detailed analysis of neuromuscular transmission in a patient with the myasthenic syndrome sometimes associated with bronchogenic carcinoma. Mayo Clin. Proc. 43: 689-713.

7. GREEN, E. L. (1981). Linkage, recombination and mapping. "Genetics and Probability in Animal Breeding Experiments," pp. 77-113, Macmillan, New York.

8. HaRris, H., AND HopkINSON, D. A. (1976). "Handbook of Enzyme Electrophoresis in Human Genetics," North-Holland, Amsterdam.

9. Hille, B. (1984). "Ionic Channels of Excitable Membranes," Sinauer, Sunderland, MA.

10. Hillyard, A. L., Doolittle, D. P., Davisson, M. T., AND RoDERICK, T. H. (1991). Locus map of mouse. Mouse Genome 89: $16-30$.

11. Hoggan, M. D., Halden, N. F., Buckler, C. E., AND KozaK, C. A. (1988). Genetic mapping of the mouse $c$-fms protooncogene to chromosome 18. J. Virol. 62: 1055-1056.

12. Hosoe, S., Brauch, H., Latif, F., GlenN, G., Daniel, L., Bale, S., ChoYke, P., Gorin, M., Oldfield, E., Berman, A., Goodman, J., OrcutT, M. L., Hampsch, K., Delisio, J., Modi, W., McBride, W., ANGlard, P., Weiss, G., WaLTHER, M. M., LineHAN, W. M., LeRMaN, M., AND ZBAR, B. (1990). Localization of the Von Hippel-Lindau disease gene to a small region of chromosome 3. Genomics 8: 634-640.

13. KIM, Y. I., AND NEHER, E. (1988). IgG from patients with Lambert-Eaton syndrome blocks voltage-dependent calcium channels. Science 239: 405-408.

14. KoK, K., Osinga, J., CarritT, B., Davis, M. B., VAN DER Hout, A. H., van DER Veen, A. Y., LANDSVATER, R. M., DE LeiJ, L. F. M. H., Berendsen, H..H., Positmus, M. P. E., Poppema, S., AND Buys, C. H. C. H. (1987). Deletion of a DNA sequence at the chromosomal region $3 \mathrm{p} 21$ in all major types of lung cancer. Nature 330: $578-581$.

15. LENNON, V. A., AND LAMBERT, E. H. (1989). Autoantibodies bind solubilized calcium channel $\omega$-conotoxin complexes from small cell lung carcinoma: A diagnostic aid for Lambert-Eaton myasthenic syndrome. Mayo Clin. Proc. 64: 1498-1504.

16. LitT, M., Luty, J., KwaK, M., Alden, L., Magenis, R. E., AND MANDEL, G. (1989). Localization of a human brain sodium channel gene (SCN2A) to chromosome 2. Genomics 5 : 204-208.

17. Llinas, R., Sugrmori, M., Lin, J-Z., AND Cherksey, B. (1989). Blocking and isolation of a calcium channel from neurons in mammals and cephalopods utilizing a toxin fraction 
(FTX) from funnel-web spider poison. Proc. Natl. Acad. Sci. USA 86: $1689-1693$.

18. Login, I. S., Kim, Y. I., Judd, A. M., SPangelo, B. L., AND MACLEOD, R. M. (1987). Immunoglobulins of LambertEaton myasthenic syndrome inhibit rat pituitary hormone release. Ann. Neurol. 22: 610-614.

19. Lyon, M. F., AND KIRBY, M. C. (1991). Mouse chromosome atlas. Mouse Genome 89: 37-59.

20. Mattei, M-G., De The, H., Mattei, J-F., Marchio, A., TtoLAIS, P., AND DEJEAN, A. (1988). Assignment of the human hap retinoic acid receptor RARB gene to the p24 band of chromosome 3. Hum. Genet. 80: 189-190.

21. McBride, O. W., Battle, J., Hollis, G. F., Swan, D. C., SIEBENLIST, U., AND LEDER, P. (1982a). Localization of human variable and constant region immunoglobulin heavy chain genes on subtelomeric band q32 of chromosome $14 . \mathrm{Nu}$ cleic Acids Res. 10: 8155-8170.

22. McBride, O. W., Hieter, P. A., Hollis, G. F., Swan, D. C., OTLEY, M. C., AND LEDER, P. (1982b). Chromosome localization of human kappa and lambda immunoglobulin light chain constant region genes. J. Exp. Med. 155: 1480-1490.

23. McBride, O. W., Swan, D. C., Santos, E., Barbacid, M., Tronick, S. R., AND AARONSON, S. A. (1984). Localization of the normal allele of $\mathrm{T} 4$ bladder carcinoma oncogene to chromosome 11. Nature (London) 300: 773-774.
24. NADEAU, J. H. (1989). Maps of linkage and synteny homologies between mouse and man. Trends Genet. 5: 82-86.

25. Nowycky, M. C., Fox, A. P., AND TsIen, R. W. (1985). Three types of neuronal calcium channels with different calcium agonist sensitivity. Nature (London) 316: 440-443.

26. Perez-Reyes, E., Kim, H. S., Lacerda, A. E., Horne, W., Wei, X., RAMPE, D., CAMPBell, K. P., BROWN, A. J. M., AND BIMBAUMER, L. (1989). Induction of calcium currents by the expression of the $\alpha 1$ subunit of the dihydropyridine receptor from skeletal muscle. Nature (London) 340: 233-236.

27. Sambrook, J., Fritsch, E., AND Maniatis, T. (1989). "Molecular Cloning: A Laboratory Manual," 2nd ed., Cold Spring Harbor Laboratory, Cold Spring Harbor, NY.

28. SouTHERN, E. M. (1975). Detection of specific sequences among DNA fragments separated by electrophoresis. $J$. Mol. Biol. 98: 503-517.

29. Tanabe, T., Beam, K., Powell, J. A., And Numa, S. (1988) Restoration of excitation-contraction coupling and slow calcium current in dygeneic muscle by dihydropyridine receptor complementary DNA. Nature (London) 336: 134-139.

30. Whang-Peng, K., Kao-Shan, C. S., Lee, E. C., BunN, P. A., CARNeY, D. N., Gazdar, A. F., AND MinNA, J. D. (1982). Specific chromosome defect associated with human small-cell lung cancer: Deletion 3p(14-23). Science 215: 181-182. 